\section{MEMORIAL STATUE OF THE LATE MUNGO PARK.}

To the Editor of THE LANCET.

SIR,-It has been proposed to erect a statue at Selkirk in memory of Mungo Park, the foremost of all our African explorers. Selkirk has been selected, as being the county town of the shire in which he was born, and in which he passed many years as apprentice to a country surgeon, to whose danghter he was married, and whose son accompanied him on his last fatal expedition. The sum already raised is $£ 150$; this is all that is at present at the command of the committee who have taken charge of the getting up of the monument. The execution of the work has been entrusted to Mr. Currie, also a native of Selkirkshire, and who has already executed in wood several very beautiful works. The sum, as I have said, at the disposal of the committee is $£ 150$; but to finish the monument so as fully to realise the idea of the sculptor would require at least the further sum of $£ 250$ to be raised. At present, means are being taken to effect this; and I have thought it right to help forward the good cause by bringing the matter before your numerous readers. Our profession should feel no slight interest and no slight pride in Mungo Park, seeing that he belonged to our hard-working body. When at Peebles he stated to Sir Walter Scott that he considered a country doctor had to get through more hard and harassing work than he had encountered whilst exploring the wilds and deserts of Africa. I think it would be a proper and gracious thing in our brethren in England (many of whom are natives of Scotland, and have a deep and abiding interest in all that concerns her), ont of their abundance, to help in raising this sum. I therefore, through your columns, make this appeal to them. Monuments or statues to medical men are not very common things; and therefore, when a fair and proper object of this kind is presented, I think the profession should sapport it. It is a thing fitted to cover us with shame that more than fifty years have passed since Mungo Park died on the banks of the Niger, - the first of that noble line of explorers who have attempted, and that so successfully, to dispel the darkness that covered as with a cloud the mysterious rovers of Central Africa, and increased our knowledge of, and extended our power and fame in, that long-neglected country,--and that, as yet, no stone or monument should, in his own well-loved country, tell the story of his daring and his dying. If any of your readers feel inclined to subscribe to this monument, and so do something to honour one to whom honour is due, I shall be most happy to receive their subscriptions. I an, Sir, yours truly,

St. John's, Melrose, July, 1858 . WM. N. Brown, M.D.

\section{T H E I A T E D R. S N O W. To the Editor of The LANCET.}

SrR, - Your correspondent, Mr. Attree, suggests a tribute to the memory of Dr. Snow for his amiable qualities; and well do I remember the happy and truthful expression contained in a testimonial to his merit, written by all eminent member of our profession, "that he possessed a temper which nothing could provoke." These qualities, no doubt, rendered him dear to all who had the happiness of knowing him; but it is due to him that both the profession and the public should be made aware of his great labours in the cause of sanitary science. I believe that since the days of Jenner no physician has rendered more important service to mankind than Dr. Snow.

When his doctrine respecting the mode in which cholera is communicated becomes comprehended by secretaries-of-state and generals commanding-in-chief, as is the household word "vaccination," then " outbreaks" of cholera-that is, large numbers of persons attacked at once in a district (a phenomenon well known in the history of the disease) will become rare events.

If Dr. Snow ever inferred too much from the facts which he so laboriously collected, at least he perceived the fallacies of that theory, propounded by Mr. Chadwick, which referred to fetid odours as the dwelling-place of cholera (an approximation, indeed, to the truth): he confidently asserted that stench is not pestiferous, as declared by Act of Parliament-an opinion which is confirmed by the able paper of Dr. Barnes in your journal of last week. Surely stinks are nuisances so intolerable that they require no argument or pseudo-theory for their suppression. Let them be remedied on their own very obvious grounds, and at any cost.
Now, although the important views embraced by Dr. Snow are very difficult to study properly, although an ardent mind may have led him to the adoption of some inferences not quite warranted by the facts, which will retard their progress; and although ephemeral criticism has been uniformly against him, yet I venture confidently to predict, that the facts which have been brought to light by his indefatigable industry will prove to posterity that he was by far the most important investigator of the subject of cholera who has yet appeared. His premature death may possibly accelerate the study of the views which be has so ingeniously advanced.

I am, Sir, your obedient servant,

Great Marlborough-street, July, 1858. J. G. FreNCH, F.R.C.S.

\section{THE MARSHALL HALL METHOD OF TREAT. MENT IN ASPHYXIA.}

To the Editor of THE LANCET.

SIR,-A novel and important discovery like Dr. Marshals Hall's should, I think, be still further supported by cases. I, therefore, beg to state that $\mathrm{I}$ succeeded in resuscitating $\mathrm{by}$ the Ready Method, two children apparently dead at birtl. There was nothing particular in the first case; but in the second I found the child with a footling presentation, in the world, excepting the head, and had been in that position abont ten minutes, with the face to the sacrum. The funis was twice round the neck. I delivered as quickly as I could. The infant gave no signs of life, and I thought it almost useless to try any plan. But after proceeding a short time with Dr. Marshali Hall's, the child began to breathe, and in about twenty minates I succeeded in my endeavours. Now, luring the time the child's head was in the vagina it had imbibel a considerable quantity of glutinous discharge from the mother, which came away by degrees as it was turned on its face. That alone, $I$ conceive, was sufficient to have hindered the ingress of air hac it been kept in the upright position, which the old plan of $a$ warm-bath rendered necessary. The old plan conld be sethom used as quickly as the cases required, especially in the houses of the poor, who seldom hare the requisite quantity of warm water at hand, or the pan or bath ready to receive the child.

Dr. Marshall Hall's plan, therefore, pre-eminently stands forth as "The Ready Metbod."

I am, Sir, your obedient servant,

Colchester, July, 1858. JAS. Monss CHURChILL, M.R.C.S.

\section{ITALIAN HOSPITALS.}

(Communicated by J. G. FildDiGE, M.D.)

ITALY has never been much celebrated for leechcraft. Ever now, in these days of enlightenment and progress, she stands almost in the same position with regard to medical science as she did fifty years ago. And yet the mombers of the profession themselves are not the cause of this. The government treats everything tending to enlighten an? improve the position of the people with the greatest apathy; conseguently medical men do not find it their interest to devote themselves to a profession which is scarcely ever looked upon with respect. But there is one thing that medical men in charge of hospitals might do, in order to prevent obloquy being cast on their professional fame, and that is-they might pay more attention to the internal regulation of these institutions with regard to cleanliness and order, so that they might not shock the senses of every person who might visit them.

A short time ago I had an opportmity of visiting most of the principal Italian hospitals, and I must confess that some of them are not only a disgrace to the profession, but a discrace to the country they are in. There is one of the sonthern Italian hospitals, for instance, the Hospital for Incurabies at Naples, which would astonish some of our Parisian or London confrères, were they to visit it. It is situated in the old part of the city, is surrounded by high houses and narrow strets, and it contains beds for about fifteen hundred patients. I visited it in company with a German physician, and we were allowed to walk through the wards witnout any person paying the slightest attention to us, with the exception of three or rour priests, who were seated at a table in one of the wards that we passed through. In each ward there were perhaps from 100 to 150 patients, a great number of whom were zuffering from lurg $10: 3$ 